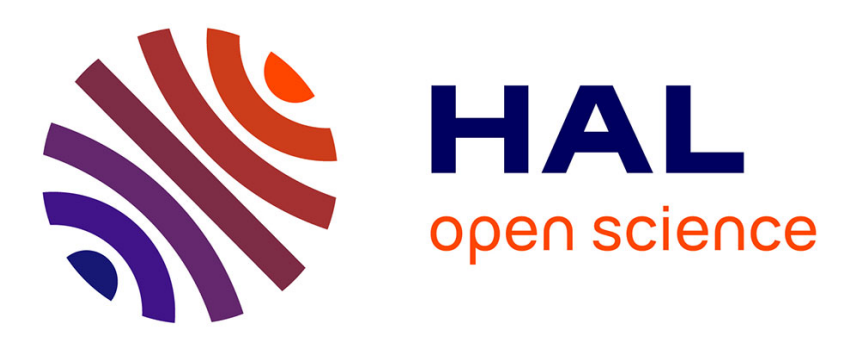

\title{
Open-Source Three-Dimensional Printable Infant Clubfoot Brace
}

Benjamin Savonen, John Gershenson, Jennifer K Bow, Joshua Pearce

\section{To cite this version:}

Benjamin Savonen, John Gershenson, Jennifer K Bow, Joshua Pearce. Open-Source ThreeDimensional Printable Infant Clubfoot Brace. Journal of Prosthetics and Orthotics, 2019, pp.1. 10.1097/JPO.0000000000000257 . hal-02111344

\section{HAL Id: hal-02111344 \\ https://hal.science/hal-02111344}

Submitted on 26 Apr 2019

HAL is a multi-disciplinary open access archive for the deposit and dissemination of scientific research documents, whether they are published or not. The documents may come from teaching and research institutions in France or abroad, or from public or private research centers.
L'archive ouverte pluridisciplinaire HAL, est destinée au dépôt et à la diffusion de documents scientifiques de niveau recherche, publiés ou non, émanant des établissements d'enseignement et de recherche français ou étrangers, des laboratoires publics ou privés. 
Benjamin SAVONEN ${ }^{1}$, John GERSHENSON ${ }^{1}$, Jennifer K. BOW ${ }^{2}$, Joshua M. PEARCE ${ }^{2,3, *}$

1. Department of Mechanical Engineering-Engineering Mechanics, Michigan Technological University, Houghton, MI 49931, USA

2. Department of Materials Science \& Engineering, Michigan Technological University, Houghton, MI 49931, USA

3. Department of Materials Science \& Engineering and Department of Electrical \& Computer Engineering, Michigan Technological University, Houghton, MI 49931, USA,

* Corresponding author: pearce@mtu.edu

Conflicts of interest: None declared

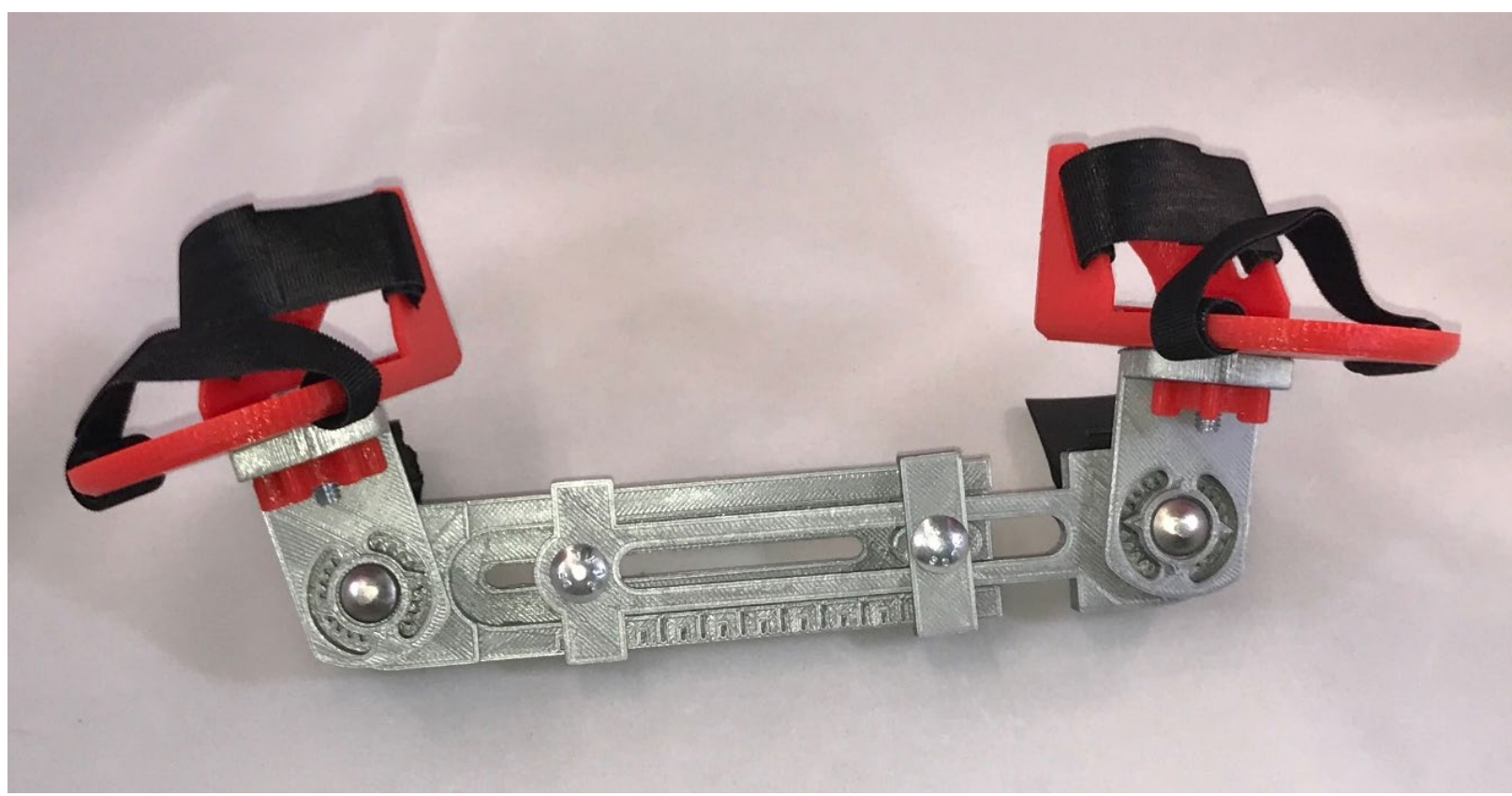

\section{Background}

Open-source, self-replicating rapid prototypers (RepRaps) have radically reduced the costs of 3-D printing while expanding its access. 3-D printing's model of distributed manufacturing can produce medical technologies at significantly reduced costs. We investigate this potential by evaluating the viability of an open-source 3-D printable infant clubfoot brace.

\section{Methods}

Starting with a list of key features present in currently available clubfoot braces, a 3-D printed clubfoot brace was developed in free and open-source CAD software (FreeCAD) to enable future customization. Poly-lactic acid (PLA), a biodegradable and recyclable bioplastic was selected among the various commercial 3-D printable materials based on strength and cost.

\section{Results}

The results show that the open-source clubfoot brace matches or surpasses the physical features and mechanical degrees of freedom of all commercial- and non-profit-developed brace designs while substantially reducing the costs of the braces to hospitals and families.

\section{Conclusions}

The 3-D printed brace has the features of commercially available braces while significantly reducing the cost, making this clubfoot brace particularly appropriate for use in developing countries. In addition, the results indicated that this model of distributed manufacturing of medical technology is technically and economically appropriate through much of the Global South. 
Preprint: Savonen, B., Gershenson, J., Bow, J.K.; Pearce, J.M., Open-Source Three-Dimensional Printable Infant Clubfoot Brace, Journal of Prosthetics and Orthotics: 2019. doi: 10.1097/JPO.0000000000000257

Level of Evidence: II

Keywords: clubfoot, clubfoot brace, foot abduction orthosis, 3-D printing, distributed manufacturing.

\section{Background}

Congential talipes equinovarus (clubfoot) is one of the most common congenital physical deformities, with an incidence of at least one case per 1000 births $^{1-3}$. The condition is characterized by infants being born with a foot in a position of cavus, forefoot adduction and calcaneal equinovarus ${ }^{1-3}$. The condition may be idiopathic or associated with other medical conditions $^{1-3}$. In developed countries, clubfoot is identified before or at the time of birth and is treated in early infancy ${ }^{4-8}$. Idiopathic clubfeet are effectively treated using the Ponseti method of weekly manipulation and casting, followed by Achilles tenotomy and a bracing protocol that includes a foot abduction orthosis (FAO or "boots and bar" brace shown in Figure 1) to prevent deformity recurrence ${ }^{4-8}$. The child initially wears the brace full-time except for bathing ( $>95 \%$ of a typical day) for the first three months, followed by weaning it to nap and nighttime wear until the age of four years ${ }^{4-8}$. In developing countries, where treatment options may be far less available, however, clubfoot can lead to life-long disability ${ }^{9}$. In East Africa, in particular, clubfoot may be at least twice as prevalent ${ }^{2}$ with up to 8 cases per 1000 births $^{10}$. Even in situations where treatment is possible, the costs of the FAOs are expensive. If the patients' families do not comply with the FAO bracing after correction of the deformities, relapse is common ${ }^{11}$. While still more expensive to American and European families $(>\$ 300$ in the U.S. and Europe ${ }^{12}$ ), the cost of braces (bar and AFO) to families across the developing world (\$150 in China ${ }^{13}$, \$90 - \$200 in Latin America ${ }^{14}$, and an average of $\$ 60$ in Africa ${ }^{15}$ ) can still be prohibitively expensive.

3-D printing has been shown to be a positive method of democratizing manufacturing for sustainable development, while radically reducing costs for products in marginalized communities ${ }^{16-20}$. This has been made possible by the technological evolution of the selfreplicating rapid prototyper (RepRap), an open-source 3-D printer that costs as little as a few hundred dollars and can fabricate more than half of its own parts ${ }^{21-23}$. The application of 3-D printers in the developing world has enabled the manufacturing of necessities in the field following humanitarian crises by groups such as Field Ready ${ }^{24,25}$. In addition, these low-cost open-source 3-D printers have been shown to be useful for fabricating both scientific and medical equipment ${ }^{26-32}$. It is thus possible that this method of distributed manufacturing could be useful for producing low cost FAO for clubfoot patients.

To investigate the potential of distributed manufacturing of an FAO for clubfoot patients in the developing world, this study makes a careful investigation of the use of RepRap 3-D printers to fabricate an open-source clubfoot brace.

\section{Methods}

The methodology includes first selecting among the various commercial 3-D printing materials based on material properties and cost, developing an open-source design using only open-source tools, and describing the open-source 3-D printer used and the settings to fabricate the clubfoot brace. Then, the brace's features were examined to ensure that it met the required features for foot abduction orthoses designed for treating clubfoot. Finally, this brace was then examined by doing a cost and functionality comparison with existing designs.

\subsection{Material Selection}

In the RepRap community, poly-lactic acid (PLA), a biodegradable and recyclable bioplastic, is the most popular 3-D printing material, being available from the vast majority of $3-\mathrm{D}$ printing supplies vendors. PLA has a relatively low melting point, $150^{\circ}-160^{\circ} \mathrm{C}$, thus requiring less energy to print - a distinct advantage for off-grid applications in the developing 
world $^{33,34}$. The mechanical properties of RepRap 3-D printing materials are well established ${ }^{35,36}$ and PLA has the highest strength to cost ratio for commercial 3-D printing filaments ${ }^{37}$, and was thus chosen for the brace in this study.

\subsection{Open-Source Design}

The open-source clubfoot brace was entirely designed with FreeCAD, an open-source CAD software ${ }^{38}$, which will enable customization or changes by anyone in the world with no software costs. The design was made for ease of printing (e.g., minimizing overhangs and material usage, while achieving strength and dimensional accuracy). It was created with the intent of being able to meet criteria collected from the literature and shown in Table 1.

The features determined to be of importance in the design of the FAO are as follows: (1) the ability to maintain foot positioning in order to prevent relapses, (2) the ability to adjust the angle of abduction, (3) the ability to dorsiflex the feet is an optimal feature for proper bracing ${ }^{12,39-41}$. An adjustable width between the feet allows for a more cost effective product, as the brace needs to be replaced far less frequently as the child grows. The ability of the foot pads to move independently and attach and detach from the abduction bar increases comfort and encourages proper usage ${ }^{42}$.

\subsection{3-D Printer Settings}

Although any RepRap class FFF 3-D printer capable of printing PLA, with or without a heated bed could fabricate this open source design ${ }^{43}$, the 3-D printer used to fabricate the brace components was a MOST delta RepRap ${ }^{44}$. Cura version $15.04 .6^{45}$ was the software used to slice the CAD models into printing layers using the following settings: layer height of $0.2 \mathrm{~mm}$, shell thickness of $1 \mathrm{~mm}$, fill density of $80 \%$, print speed of $40 \mathrm{~mm} / \mathrm{s}$, and a print temperature of $185^{\circ} \mathrm{C}$.

\subsection{Cost Calculations}

A multivariable cost analysis was run on the three primary driving variables in the cost of locally manufacturing the clubfoot brace - 1) labor cost, 2) filament cost, and 3) electricity cost. Because economic specifics can vary greatly throughout the developing world, the cost sensitivity analysis was performed using data collected on labor, electricity, and filament costs in the context of manufacturing them in a single economy: Kenya. Clubfoot is especially prevalent in Kenya, with clubfoot being the most common congenital malformation occurring throughout the country with approximately 3 instances per 1000 children $^{46}$. Even when subsidized, the cost of procuring braces in Kenya can be difficult for many Kenyan families ${ }^{47}$.

Kenyan labor costs were varied from $\$ 0$ (volunteers or zero marginal cost for existing employees that could periodically monitor the 3-D printer and do the simple assembly procedure while doing other tasks) to $\$ 1.30 / \mathrm{hr}$ (the government dictated wage for a Kenyan machinist in an urban $\operatorname{area}^{48}$ ) in $\$ 0.10$ increments. Three commercial filament sources were found to be available in Kenya (prices, including shipping and VAT shown in Table 2). It should be noted that these are real consumer costs in Kenya and not the costs per kg at the manufacturer. These values were then compared to less than $\$ 0.10 / \mathrm{kg}$ for filament generated by a recyclebot (post-consumer waste plastic extruder capable of making 3-D printer filament from thermopolymers $)^{49,50}$.

The electricity was varied between the cost to run a solar powered printer $(\$ 0 / \mathrm{kWh})$, to $21.08 \mathrm{KES} / \mathrm{kWh}(\$ 0.2029 / \mathrm{kWh})$, which is the highest standardized rate for electricity in Kenya based on January 2017 data $^{52}$.

To calculate the total cost of producing the entire assembly, methodology from Laplume et al. ${ }^{53}$ was used and modified to include labor costs (Equations 1-5). Equation 1 shows the components of the cost of the brace - electricity, materials, and labor. 


$$
\begin{aligned}
& \mathbf{C =} \mathbf{C E}_{\mathbf{E}}+\mathbf{C}_{\mathbf{c}}+\mathbf{C}_{\mathbf{L}}+\mathbf{C}_{\mathbf{h}} \\
& \text { Where } \\
& \mathbf{C}=\text { Total cost of producing the brace }(\$) \\
& \mathrm{C}_{\mathrm{E}}=\text { Cost of electricity }(\$) \\
& \mathrm{C}_{\mathrm{C}}=\text { Cost of filament consumed }(\$) \\
& \mathrm{C}_{\mathrm{L}}=\text { Cost of labor }(\$) \\
& \mathrm{C}_{h}=\text { Cost of non-printed hardware }(\$)
\end{aligned}
$$

Equation 2

The energy used by the printer was measured directly with a multimeter $(+/-0.01 \mathrm{kWh})$ and the value of $C_{u}$ is dependent upon the cost of electricity fees at the site of manufacturing.

$$
\mathbf{E}=\mathbf{P}_{\mathbf{p}} \mathbf{t}+\mathbf{E}_{\mathbf{w}}
$$

Where

Equation 3

$\mathrm{P}_{\mathrm{p}}=$ Average power use while printing $(\mathrm{kW})$

$\mathrm{t}=$ Time of print (hr)

$\mathrm{E}_{\mathrm{w}}=$ Energy consumption for warming the printer $(\mathrm{kWh})$

The cost of filament consumed is calculated by looking at the cost of the filament per kilogram and multiplying it by the number of kilograms used, as seen in Equation 4.

\section{$\mathbf{C}_{\mathbf{C}}=\mathbf{m}_{\mathrm{p}} \mathbf{C}_{\mathrm{f}}$}

Where

Equation 4

$$
\mathrm{m}_{\mathrm{p}}=\text { Mass of the filament used in print }(\mathrm{kg})
$$

$$
\mathrm{C}_{\mathrm{f}}=\text { unit cost of filament }(\$ / \mathrm{kg})
$$

Finally, labor costs can be calculated with Equation 5. This assumes that the operator is paid for the entire time the printer is in operation, though due to the automated nature of 3-D printing, labor charges may only be incurred while preparing and completing prints.

$$
\begin{aligned}
& \mathbf{C}_{\mathbf{L}}=\mathbf{w t} \\
& \text { Where } \\
& \quad \mathrm{w}=\text { Hourly wages }(\$ / \mathrm{hr})
\end{aligned}
$$

Equation 5

\section{Results}

\subsection{Design and Biomechanics}

The final clubfoot brace, based upon the requirements discussed in section two, is shown in Figure 3. There are 13 printed components in the clubfoot brace assembly (Figure 2). These parts, their masses, their required printing time, and their estimated material costs (using PLA costs of $\$ 30 / \mathrm{kg}$ ) can be seen in Table 3. The non-printed components can be seen in Table 4 . The total cost of the materials necessary to produce the clubfoot brace was found to be $\$ 10.92$ through totaling the values seen in Tables 3 and 4 .

The base of the brace is comprised of top and bottom sliders together held together by the closing bracket, two carriage bolts, and two nuts press-fit into printed flattened knob pieces. The tightening and loosening of these knobs allows for adjusting the feet width. The minimum width of the braces is $18 \mathrm{~cm}$, and it can be extended to $27 \mathrm{~cm}$ according to the notches along the edge of the slider piece. The brace should be adjusted to place the feet shoulder width apart, and the distance between the feet should be increased as the child grows.

At the far end of the slider pieces are attachment points for the two angle brackets. These brackets (Figure 3) can be printed at different angles to allow for dorsiflexion (included in the source code are predefined angle brackets with angles of 90, 95, 100, 105, and 110 degrees). 
Preprint: Savonen, B., Gershenson, J., Bow, J.K.; Pearce, J.M., Open-Source Three-Dimensional Printable Infant Clubfoot Brace, Journal of Prosthetics and Orthotics: 2019. doi: 10.1097/JPO.0000000000000257

As shown here they are at 90 degrees, which provides a dorsiflexion of 0 degrees. They are able to be locked into place or, if reversed (Figure 4), allow for motion of the legs as the footpads are not locked relative to the slider pieces.

The footpads are also able to be tightened onto the angle brackets with carriage bolts and locked into place by securing them onto interlocking ridges on the angle brackets (Figure 5). Figure 6 shows the fully assembled clubfoot brace and highlights the degrees of motion that it is able to be moved and locked into. Due to the simplicity of the assembly, the infant's shoes can be first attached to the footpad via Velcro straps before attaching the footpad to the bar. The shoes employed should be "low rise" at the heel to allow observation that the heel remains against the foot pad, which is lost if a "high top" shoe is employed.

This open-source clubfoot brace detailed here was evaluated based for the positive presence of FAO design features outlined in Table 1 above. The results of this evaluation and a comparison of the features, cost, and manufacturability of the open-source 3-D printed brace and four other existing FAOs can be seen in Table 5 .

The design of the FAO is such that the affected feet maintain hip abduction of 70 degrees and dorsiflexion of 15 degrees (with a 105 degree L bracket) to maintain static stretch on the posteromedial ligamentous structures of the hindfoot and (tibialis anterior, tibialis posterior, flexor digitorum longus, flexor hallucis longus and the deltoid and spring ligaments) ${ }^{54}$. These posteromedial soft tissue structures are thought to be the main etiology of recurrence of deformity when the maintenance phase of the deformity correction is not complied with. Fibrosis and contracture of these tissues that have been stretched out in the active deformity correction phase allows recurrence of the deformity. To maintain correction, compliance with the bracing protocol is critical. The ability of parents to comply with the bracing treatment is made possible by having an affordable and seemingly comfortable brace with which the parents can treat their children. The parents must understand the reason for the bracing and must be able to easily fit a well-sized brace to their child. As the components of the 3-D printed brace are individually printed, sizing the brace to the child, even as the child grows is economical and it is possible to achieve a custom fit. The 3-D printed brace described herein is modelled after the Dobb's dynamic brace to allow flexion and extension of each leg independently while maintaining the feet in the abducted and dorsiflexed position ${ }^{55}$.

It should be noted that the customization and degrees of freedom possible with this open-source design requires education of the people providing and fitting the braces so that the feet are placed and maintained in an optimal position. It should also be noted that the brace is designed and made of hard plastic and as such, the shoes worn by the child need to provide protection to the child's skin from developing pressure points and sores. The use of the child's own shoes within the brace also allows an additional degree of customization of the brace. If shoes are not to be worn with the brace, the brace would need to be padded to provide protection to the skin. However, it should be pointed out that common shoes may not achieve the desired biomechanical principles, and infant / toddler shoes also may slip, with the inability to hold a child's foot in a desired position for a prolonged amount of time. Users should carefully consider the shoes to ensure that the Velcro straps are adequate to hold the positions over extended periods.

\subsection{Cost Analysis}

While the open-source 3-D printed brace is in the same cost range as the Steenbeck ${ }^{56}$ and Miraclefeet ${ }^{57}$ braces, the open-source brace was more comparable in features to the commercially available models. Its ability to be locally manufactured also presents an advantage over commercial models and the Miraclefeet in allowing for point-of-use customization and creating local employment opportunities similar to the Steenbeck model.

Using Equations 1-5 and the values seen in Table 6, a cost sensitivity analysis was 
performed. The mass of the filament used $\left(\mathrm{m}_{\mathrm{p}}\right)$ and the time used to print the parts $(\mathrm{t})$ were calculated using the open-source 3-D printing software Cura. The power usage $\left(\mathrm{P}_{\mathrm{P}}\right)$ and energy consumption $\left(\mathrm{E}_{\mathrm{w}}\right)$ were monitored using a multimeter during the printing.

Using the inputs from Table 6, a starting scenario was created with the following assumptions:

1. Printing is considered to be mostly automated and done by professional while working on other tasks (labor cost of $\$ 0 / \mathrm{hr}$ ). This estimate is relevant when there is no opportunity cost to using existing salaried employee (e.g., the use of a lab technician or other position that is paid a fixed cost, and for which there is no opportunity cost for them working on the fabrication of the device). It should be noted that with the STL files provided by this study enable anyone familiar with FFF-based 3-D printing operation to begin the prints in less than one minute. Although the actual printing will take over 20 hours, 3-D printers operate unattended and no labor is involved in the printing process itself. The operator then needs to remove the printed components from the bed and assemble them in a process that takes only a few minutes depending on the experience of the individual. The base case used here does not include the labor cost as setting up prints, removing them and assembly are roughly equivalently time consuming to placing an order, inputting payment information, acquiring and unpacking/removing packaging from a commercial brace.

2 . There is an electrical fee of $\$ 0.19 / \mathrm{kWh}$ (Kenyan electricity costs for domestic usage ${ }^{52}$ )

3. Filament is purchased at $\$ 30 / \mathrm{kg}$ (least expensive commercial option found in Nairobi although filament is available less expensively elsewhere).

Using these assumptions and Equations 2-5 yields a cost of electricity $\left(\mathrm{C}_{\mathrm{E}}\right)$ of $\$ 0.16$, a cost of filament consumed $\left(\mathrm{C}_{\mathrm{c}}\right)$ of $\$ 8.22$, a cost of labor $\left(\mathrm{C}_{\mathrm{L}}\right)$ of $\$ 0$, and a cost of non-printed hardware $\left(C_{L}\right)$ of $\$ 2.70$. Summing these values together using Equation 1, the total material cost of the brace is calculated to be $\$ 11.08$.

By varying each one of three variable inputs $\left(C_{u}, C_{f}, w\right)$ in the ranges specified in Table 7, while keeping the other two variables constant (e.g. varying $C_{u}$ while keeping $C_{f}$ and $w$ constant), a sensitivity analysis was conducted to show how the price of the 3-D printed brace varies. Figure 6 shows the range of costs that can be incurred with variations in the electrical, material, and labor costs. Figure 7 also highlights each of the filament sources listed in Table 2 above.

The cost of the 3-D printed brace can be seen to vary significantly depending upon the source of filament, electricity costs, and any costs that may be incurred from labor. As seen in Figure 6, the variable with the most potential for affecting the final cost of the brace is the labor. In the extreme case, the labor cost is set at a local machinist's wages ( $\$ 1.30 /$ hour) for the entirety of the print time and results in a final cost for the brace of over \$37. It should be made clear that this is an unrealistic scenario as the ' $3-\mathrm{D}$ printer operator' would use the vast majority of the 20 hours on other tasks, while only spending a few minutes focused on brace manufacture. Realistically the labor costs in this market are well under one U.S. dollar with all actual opportunity time cost included.

The cost of the filament also has significant effects on the final cost of the brace, with the most expensive filament source resulting in a brace costing over \$30. On the other hand, using recycled filament produces a brace costing less than $\$ 5$ in total to manufacture. Electricity costs vary the least, with a total fluctuation in cost being $\$ 0.17$.

Finally, when comparing this method of distributed manufacturing to conventional manufacturing the cost of tooling is often included in the manufacturers cost analysis. In this case, the tooling cost was $\$ 500$ for the 3-D printer and follows previous estimates of a minimum of a five-year lifetime ${ }^{61}$ as the most likely components to fail on the printer can be manufactured 
by the printer itself. Although it could be used to manufacture a wide range of medical devices with substantial economic savings ${ }^{62-64}$, it is instructive to determine the tooling cost for an individual FAO. If it is conservatively assumed that 1 FAO can be manufactured per day with a printer over 5 years, 1825 FAOs can be made with a machine resulting in a tooling cost of 27.4 cents/FAO. One 3-D printer operator can of course manage many 3-D printers simultaneously so if a given medical facility needed more FAOs/day additional printers could be used. One person working full time with hand tools manufacturing low-cost Steenbeek braces can produce about 100 braces per month. ${ }^{65}$ Thus, 3-4 conventional 3-D printers under a single operator would be needed to produce the same number of 3-D printed FAOs/month. It should be noted that the values given in this study are not the maximum production speed, but those that should be able to be achieved widely. With 3-D printing, the number of FAOs produced per month could be increased by increasing print speed and/or layer height, but there are physical limits to the fabrication speed of a single headed printer. However, for production of many of the same parts, 3-D printer manufacturing can be scaled by using a 3-D printer with multiple heads. So, for example, this can be done vertically with a quad-delta style 3-D printer that could produce four identical FAOs per day ${ }^{66}$ or a multi-head (5 head) Cartesian style printer $^{67}$ on an open source Gigabot platform ${ }^{68}$ that could produce five identical FAOs per day.

In addition to offering greater functionality at lower costs, this approach to FAOs also has the advantage of reducing the environmental impact (albeit small) from the manufacturing process due to the decrease in shipping embodied energy and the ability to print with partial infill $^{69,70}$. Finally, these cost estimations for the device can be considered conservative as recycling post-consumer thermoplastic waste into 3-D printing filament using recyclebots (waste plastic extruders) has already been shown to be feasible $49,50,71-76$, which indicates that the cost of the printed parts could be significantly reduced as shown in Table 5.

\subsection{Open Source Designs and Future Work}

The open source design was intended to be printed in PLA on any number of FFF-based 3-D printers. Previous work ${ }^{77}$ has shown that increasing the thickness of a 3-D printed polymer based mechanical component as compared to an aluminum component was sufficient to match the strength as was done here. However, it has been pointed out that in addition to the changes in strength expected from slicing ${ }^{78,79}$, materials ${ }^{80}$, and $\operatorname{color}^{36}$, there is also variability due to different realistic environmental conditions ${ }^{35}$. To ensure that the designed mechanical properties, are realized when printed the two step process outlined in ref. 80 is recommend, which has a reasonably high expectation that a part will have the desired tensile strengths. First, the exterior of the 3-D printed object is inspected visually for sub-optimal layers. Then, on critical components that will undergo substantial loads to determine if there has been underextrusion in the interior, the mass of the sample is measured. This mass is compared to the theoretical value using densities for the material and the volume of the object. As the infill density used in this study is $80 \%$ and the forces expected from a young child using the brace are relatively small, exterior observation is adequate unless there is a concern about filament of inconsistent diameter or properties (e.g. recycled waste used for filament without quality control ${ }^{81-84}$ ).

This article discusses both the distributed manufacturing cost and the FAO systems design and function, which enables but fails to address outcomes of the treatment of clubfoot itself. For this, future clinical work is needed using the 3-D printed FAOs. To enable this for researchers anywhere in the world, all 3-D printable designs shown here (both the FreeCAD models and STL files) are available for free at the Open Science Framework under a GNU General Public License 3.0. ${ }^{85}$

\section{Conclusions}

While treatable, clubfoot continues to prove to be a challenge to many throughout the 
Preprint: Savonen, B., Gershenson, J., Bow, J.K.; Pearce, J.M., Open-Source Three-Dimensional Printable Infant Clubfoot Brace, Journal of Prosthetics and Orthotics: 2019. doi: 10.1097/JPO.0000000000000257

developing world, and the cost of necessary orthotics can be prohibitively expensive and difficult to obtain. This study has shown that through the use of 3-D printing, it is possible to manufacture a low-cost children's foot abduction orthosis. When compared to existing alternatives for the treatment of clubfoot in the developing world, the open-source 3-D printed orthosis presented in this paper is able to have the same physical features of all of the commercial alternatives while significantly reducing the cost and allowing improved customization to occur locally. Future work is needed to test the efficacy and outcomes of these devices in the clinical environment. With continued growth of 3-D printing technology and improved material sourcing, 3-D printing can provide a cost-effective way to provide FAOs and other orthotic devices to the developing world.

\section{References}

1. Kromberg JG, Jenkins T. Common birth defects in Blacks. South African Medical Journal. 1982;62:599-602.

2. Mkandawire NC, Kaunda E. Incidence and patterns of congenital talipes equinovarus (clubfoot) deformity at Queen Elizabeth Central Hospital, Banter, Malawi. East and Central African Journal of Surgery. 2004;9(2):28-31.

3. Barker S, Chesney D, Miedzybrodzka Z, Maffulli N. Genetics and epidemiology of idiopathic congenital talipes equinovarus. Journal of Pediatric Orthopaedics. 2003;23(2):265-272.

4. Dobbs MB, Morcuende JA, Gurnett CA, Ponseti IV. Treatment of idiopathic clubfoot: an historical review. Iowa Orthopaedic Journal. 2000;20:59-64.

5. Changulani M, Garg NK, Rajagopal TS, Bass A, Nayagam SN, Sampath J, Bruce CE. Treatment of idiopathic club foot using the Ponseti method. Bone \& Joint Journal. 2006;88(10):1385-1387.

6. Jowett CR, Morcuende JA, Ramachandran M. Management of congenital talipes equinovarus using the Ponseti method. J Bone Joint Surg Br. 2011;93(9):1160-1164.

7. Moroney PJ, Noël J, Fogarty EE, Kelly PM. A single-center prospective evaluation of the Ponseti method in nonidiopathic congenital talipes equinovarus. Journal of Pediatric Orthopaedics. 2012;32(6):636-640.

8. Sætersdal C, Fevang JM, Fosse L, Engesæter LB. Good results with the Ponseti method: a multicenter study of 162 clubfeet followed for $2-5$ years. Acta Orthopaedica. 2012;83(3):288-293.

9. Mayo EA, Cuthel A, Macharia JT, Lavy CB, Mead TC. Creating a countrywide program model for implementation of a Ponseti method clubfoot treatment program in developing countries. Cure. Available at: https://cure.org/downloads/site/clubfoot/ccwcreating_a_countrywide_program_model.pdf

10. Dietz FR, Tyler MC, Leary KS, Damiano PC. Evaluation of a disease-specific instrument for idiopathic clubfoot outcome. Clinical Orthopaedics and Related Research. 2009;467(5):1256-1262.

11. Thacker MM, Scher DM, Sala DA, van Bosse HJ, Feldman DS, Lehman WB. Use of the foot abduction orthosis following Ponseti casts: is it essential? Journal of Pediatric Orthopaedics. 2005: 25(2): 225-228.

12. Lajja Desai BS, Oprescu F, DiMeo A, Morcuende JA. Bracing in the treatment of children with clubfoot: past, present, and future. Iowa Orthop J. 2010;30:15-23.

13. Lu N, Zhao L, Du Q, Liu Y, Oprescu FI, Morcuende JA. From cutting to casting: impact and initial barriers to the Ponseti method of clubfoot treatment in China. Iowa Orthopaedic Journal. 2010;30:1-6. 
Preprint: Savonen, B., Gershenson, J., Bow, J.K.; Pearce, J.M., Open-Source Three-Dimensional Printable Infant Clubfoot Brace, Journal of Prosthetics and Orthotics: 2019. doi: 10.1097/JPO.0000000000000257

14. Boardman A, Jayawardena A, Oprescu F, Cook T, Morcuende JA. The Ponseti method in Latin America: initial impact and barriers to its diffusion and implementation. The Iowa Orthopaedic Journal 2011;31:30.

15. Grimes CE, Holmer H, Maraka J, Ayana B, Hansen L, Lavy CB. Cost-effectiveness of club-foot treatment in low-income and middle-income countries by the Ponseti method. BMJ Global Health. 2016;1(1).

16. Pearce JM, Blair CM, Laciak KJ, Andrews R, Nosrat A, Zelenika-Zovko I. 3-D printing of open source appropriate technologies for self-directed sustainable development. Journal of Sustainable Development. 2010;3(4):17-29.

17. Canessa E, Fonda C, Zennaro M. Low-cost 3D printing for science, education and sustainable development. Low-Cost 3D Printing. 2013;22;11.

18. Lopes da Silva JV. 3D technologies and the new digital ecosystem: a Brazilian experience. Proceedings of the Fifth International Conference on Management of Emergent Digital EcoSystems; 2013 Oct 28; Luxembourg, Luxembourg. New York: ACM. p. 278-284.

19. Gwamuri J, Wittbrodt BT, Anzalone NC, Pearce JM. Reversing the trend of large scale and centralization in manufacturing: The case of distributed manufacturing of customizable 3-D-printable self-adjustable glasses. Challenges in Sustainability. 2014;2(1):30-40.

20. Birtchnell T, Hoyle W. 3D printing for development in the global south: The 3D4D challenge. Springer; 2014.

21. Jones R, Haufe P, Sells E, Iravani P, Olliver V, Palmer C, Bowyer A. RepRap-the replicating rapid prototyper. Robotica. 2011;29(1):177-191.

22. Bowyer, A. 3D printing and humanity's first imperfect replicator. $3 D$ Printing and Additive Manufacturing. 2014: 1(1):4-5.

23. Sells E, Bailard S, Smith Z, Bowyer A, Olliver V. Reprap: The Replicating Rapid Prototyper-maximizing customizability by breeding the means of production. Handbook of Research In Mass Customization and Personalization, Volume 1: Strategies and Concepts. New Jersey: World Scientific, 2009. p. 568-580.

24. Field Ready. (2016). Field Ready - Humanitarian Supplies Made-in-the-Field. [Online] Available at: http://www.fieldready.org/

25. Dotz AD. A Pilot of 3D Printing of Medical Devices in Haiti. In Technologies for Development. Switzerland, 2015; p. 33-44

26. Pearce JM. Open-source lab: How to build your own hardware and reduce research costs. Elsevier; 2013.

27. Zhao C, Wu Q, Clancy T, Liu X. A 3D-printed portable microindenter for mechanical characterization of soft materials. Proceedings from 2016 IEEE International Conference on Automation Science and Engineering (CASE); 2016; Fort Worth, TX. p. 201-206.

28. De Ciurana J, Serenóa L, Vallès È. Selecting process parameters in RepRap additive manufacturing system for PLA scaffolds manufacture. Procedia. 2013;5:152-157.

29. Ma T. Design of Surface Textures for Improved Resin Replenishment During Additive Manufacturing [dissertation]. Di Torino: Politecnico; 2016.

30. Hurst EJ. 3D Printing in Healthcare: Emerging Applications. Journal of Hospital Librarianship. 2016;16(3):255-267.

31. Burn MB, Ta A, Gogola GR. Three-dimensional printing of prosthetic hands for children. The Journal of Hand Surgery. 2016;41(5):e103-109.

32. Phillips B, Zingalis G, Ritter S, Mehta K. A review of current upper-limb prostheses for resource constrained settings. Proceedings of Global Humanitarian Technology Conference (GHTC); 2015 Oct 8; Seattle, WA. IEEE, 2015. p. 52-58. 
Preprint: Savonen, B., Gershenson, J., Bow, J.K.; Pearce, J.M., Open-Source Three-Dimensional Printable Infant Clubfoot Brace, Journal of Prosthetics and Orthotics: 2019. doi: 10.1097/JPO.0000000000000257

33. King DL, Babasola A. Mobile open-source solar-powered 3-D printers for distributed manufacturing in off-grid communities. Challenges in Sustainability. 2014;2(1):18.

34. Gwamuri J, Franco D, Khan KY, Gauchia L, Pearce JM. High-Efficiency SolarPowered 3-D Printers for Sustainable Development. Machines. 2016;4(1):3.

35. Tymrak BM, Kreiger M, Pearce JM. Mechanical properties of components fabricated with open-source 3-D printers under realistic environmental conditions. Materials \& Design. 2014;58:242-246.

36. Wittbrodt B, Pearce JM. The effects of PLA color on material properties of 3-D printed components. Additive Manufacturing. 2015;8:110-116.

37. Tanikella NG, Savonen B, Gershenson J, Pearce JM. Viability of Distributed Manufacturing of Bicycle Components with 3-D Printing: CEN Standardized Polylactic Acid Pedal Testing. Journal of Humanitarian Engineering. 2016. 5(1) 8-17.

38. FreeCAD: An open-source parametric 3D CAD modeler. [computer program]. Available at: http://www.freecadweb.org/

39. Bracing Tips. [Ponseti International]. Februrary 21, 2016. Available at http://www.ponseti.info/bracing-tips.html

40. Lohan I. Treatment of Congenital Clubfoot Using the Ponseti Method Workshop Manual, 2nd ed. Global Help. 2011. Available at: https://globalhelp.org/publications/books/help_clubfoottreatmentmanual.pdf

41. Staheli L. Clubfoot: Ponseti Management, 3rd ed. Global Help. 2009. Available at: https://pdfs.semanticscholar.org/abd7/c9782d66020d2d73041d10fa9b9d9e6161d6.

42. Garg S, Porter K. Improved bracing compliance in children with clubfeet using a dynamic orthosis. Journal of Children's Orthopaedics. 2009;3(4):271-276

43. Gibb A. Building open source hardware. Pearson Education, 2014.

44. Anzalone GC, Wijnen B, Pearce JM. Multi-material additive and subtractive prosumer digital fabrication with a free and open-source convertible delta RepRap 3-D printer. Rapid Prototyping Journal. 2015;21(5):506-519.

45. Cura [Computer Program] Version 15.04.6 Available at: $\mathrm{https}: / /$ ultimaker.com/en/products/cura-software

46. Wu VK, Poenaru D, Poley MJ. Burden of surgical congenital anomalies in Kenya: a population-based study. Journal of Tropical Pediatrics. 2013;59(3):195-202.

47. Kingau NW, Rhoda A, Mlenzana N. Barriers experienced by service providers and caregivers in clubfoot management in Kenya. Tropical doctor. 2015;45(2):84-90.

48. Kenyan Ministry of Labour. The Regulations of Wages (Agricultural Industry) : (Amendment). Order 201 The Labour Institutions Act. 2015. Available at: http://kenyalaw.org/k1/fileadmin/pdfdownloads/LegalNotices/LN_No.116_117_of_20 15_1_.pdf

49. Baechler C, DeVuono M, Pearce JM. Distributed recycling of waste polymer into RepRap feedstock. Rapid Prototyping Journal. 2013;19(2):118-125.

50. Zhong S, Pearce JM. Tightening the Loop on the Circular Economy: Coupled Distributed Recycling and Manufacturing with Recyclebot and RepRap 3-D Printing. Resources, Conservation and Recycling 2018:128:48-58.

51. AB3D-African Born 3D Printing [AB3D Kenya. Website]. Available at: http://www.ab3d.co.ke/shop. Accessed February 21, 2017.

52. Historic Electricity Cost Data for Kenya. [Regulus Website]. Available at: https://stima.regulusweb.com/historic Accessed February 21, 2017.

53. Laplume A, Anzalone GC, Pearce JM. Open-source, self-replicating 3-D printer factory for small-business manufacturing. The International Journal of Advanced Manufacturing Technology. 2016;85(1-4):633-642.

54. Zhao D, Liu J, Zhao L, Wu Z. Relapse of clubfoot after treatment with the Ponseti 
Preprint: Savonen, B., Gershenson, J., Bow, J.K.; Pearce, J.M., Open-Source Three-Dimensional Printable Infant Clubfoot Brace, Journal of Prosthetics and Orthotics: 2019. doi: 10.1097/JPO.0000000000000257

method and the function of the foot abduction orthosis. Clinics in Orthopedic Surgery 2014: 6(3): 245-252.

55. Desai L, Oprescu F, DiMeo A, Morcuende J A. Bracing in the treatment of children with clubfoot: past, present, and future. The Iowa Orthopaedic Journal: 2010: 30, 1523.

56. Steenbeek HM, David OC. Steenbeek Brace for Clubfoot, 2nd Ed. Global Help. 2006. Available at: https://global-help.org/publications/books/help_steenbeekbrace.pdf

57. Miracle Feet. 2018. Available at: https://www.miraclefeet.org/

58. McMaster-Carr. [McMaster-Carr Website]. Available at: https://www.mcmaster.com/\#carriage-and-plow-bolts/=15ye3gj Accessed February 21, 2017.

59. Ponseti Abduction Rotation Bars. [C-Pro Direct Website]. Available at: https://www.cprodirect.co.uk/ponseti-abduction-rotation-bars. Accessed February 21, 2017.

60. Dobbs Bar [D-Bar Enterprises Website]. Available at: http://www.dobbsbrace.com/dobbs-bar.html Accessed February 21, 2017.

61. Petersen EE, Pearce J. Emergence of Home Manufacturing in the Developed World: Return on Investment for Open-Source 3-D Printers. Technologies 2017, 5(1), 7; doi:10.3390/technologies501000

62. Chavez A, Kovarik C Open Source Technology for Medical Practice in Developing Countries. In Health Information Systems and the Advancement of Medical Practice in Developing Countries (pp. 33-59). IGI Global. (2017).

63. Pearce JM. Maximizing returns for public funding of medical research with opensource hardware. Health Policy and Technology 2017, 6(4):381-382.

64. Bhatia SK, Ramadurai KW 3-Dimensional Printing of Medical Devices and Supplies. In 3D Printing and Bio-Based Materials in Global Health (pp. 63-93). Springer, Cham (2017).

65. Carlson, D. Global Help. Personal communication. January 9, 2018.

66. Laplume A, Anzalone GC, Pearce. Open-source, self-replicating 3-D printer factory for small-business manufacturing. The International Journal of Advanced Manufacturing Technology 2016: 85(1-4): 633-642.

67. Laureto JJ, Pearce Open Source Multi-Head 3D Printer for Polymer-Metal Composite Component Manufacturing. Technologies 2017:5(2):36.

68. Re:3D. Gigabot Kit. Available : http://wiki.re3d.org/index.php?title=Gigabot_Kit

69. Kreiger M, Pearce JM. Environmental impacts of distributed manufacturing from 3-D printing of polymer components and products. In MRS Proceedings; 2013; Vol. 1492; Cambridge University Press. pp. 85-90.

70. Kreiger M, Pearce JM. Environmental life cycle analysis of distributed threedimensional printing and conventional manufacturing of polymer products. ACS Sustainable Chemistry \& Engineering, 2013: 1(12):1511-1519.

71. Kreiger MA, Mulder ML, Glover AG, Pearce JM. Life cycle analysis of distributed recycling of post-consumer high density polyethylene for 3-D printing filament. Journal of Cleaner Production. 2017;70:90-96.

72. Feeley SR, Wijnen B, Pearce JM. Evaluation of potential fair trade standards for an ethical 3-D printing filament. Journal of Sustainable Development. 2014;7(5):1-12.

73. Cruz, F, Lanza, S, Boudaoud, H, Hoppe, S, Camargo, M. Polymer Recycling and Additive Manufacturing in an Open Source context: Optimization of processes and methods. Solid Freeform Fabrication Symposium. Available at: http://sffsymposium.engr.utexas.edu/sites/default/files/2015/2015-127-Cruz.pdf/ Accessed June 10, 2016. 
Preprint: Savonen, B., Gershenson, J., Bow, J.K.; Pearce, J.M., Open-Source Three-Dimensional Printable Infant Clubfoot Brace, Journal of Prosthetics and Orthotics: 2019. doi: 10.1097/JPO.0000000000000257

74. Sanchez FAC, Boudaoud H, Hoppe S, Camargo M. Polymer recycling in an opensource additive manufacturing context: Mechanical issues. Additive Manufacturing, 2017: 17: 87-105.

75. Hamod H. Suitability of recycled HDPE for 3D printing filament [dissertation]. Helsinki: Arcada University of Applied Science.

76. Hunt EJ, Zhang C, Anzalone N, Pearce JM. Polymer recycling codes for distributed manufacturing with 3-D printers. Resources, Conservation and Recycling. 2015 30;97:24-30.

77. Wittbrodt B, Laureto J, Tymrak B, Pearce JM. (2015). Distributed manufacturing with 3-D printing: a case study of recreational vehicle solar photovoltaic mounting systems. Journal of Frugal Innovation. 2015, 1(1), 1. doi:10.1186/s40669-014-0001-z

78. Lanzotti A, Grasso M, Staiano G, Martorelli M. The impact of process parameters on mechanical properties of parts fabricated in PLA with an open-source 3-D printer. Rapid Prototyping Journal 2015, 21(5), 604-617.

79. Fernandez-Vicente M., Calle W, Ferrandiz S, Conejero A. Effect of infill parameters on tensile mechanical behavior in desktop 3D printing. 3D printing and additive manufacturing 2016, 3(3), 183-192.

80. Tanikella N G, Wittbrodt B, Pearce JM. Tensile strength of commercial polymer materials for fused filament fabrication 3D printing. Additive Manufacturing 2017, 15, 40-47.

81. Anderson I. Mechanical Properties of Specimens 3D Printed with Virgin and Recycled Polylactic Acid. 3D Printing and Additive Manufacturing 2017, 4, 110-115.

82. Pakkanen J, Manfredi D, Minetola, P, Iuliano L. About the Use of Recycled or Biodegradable Filaments for Sustainability of 3D Printing. In Sustainable Design and Manufacturing 2017; Smart Innovation, Systems and Technologies; Springer, Cham, 2017; pp. 776-785.

83. Mohammed MI, Mohan M, Das A, Johnson MD, Badwal PS, McLean D, Gibson I. A low carbon footprint approach to the reconstitution of plastics into 3D-printer filament for enhanced waste reduction. KnE Engineering 2017, 2, 234-241.

84. Mohammed MI, Das A, Gomez-Kervin E, Wilson D, Gibson I. EcoPrinting: Investigating the use of $100 \%$ recycled Acrylonitrile Butadiene Styrene (ABS) for Additive Manufacturing. Solid Freeform Fabrication 2017. Proceedings of the 28th Annual International Solid Freeform Fabrication Symposium. $\mathrm{http} / / /$ sffsymposium.engr.utexas.edu/sites/default/files/2017/Manuscripts/EcoprintingI nvestigatingtheUseof100Recycle.pdf

85. Design files Available at: https://osf.io/teg2x/ 
Preprint: Savonen, B., Gershenson, J., Bow, J.K.; Pearce, J.M., Open-Source Three-Dimensional Printable Infant Clubfoot Brace, Journal of Prosthetics and Orthotics: 2019. doi: 10.1097/JPO.0000000000000257

\section{Figure Captions}

570

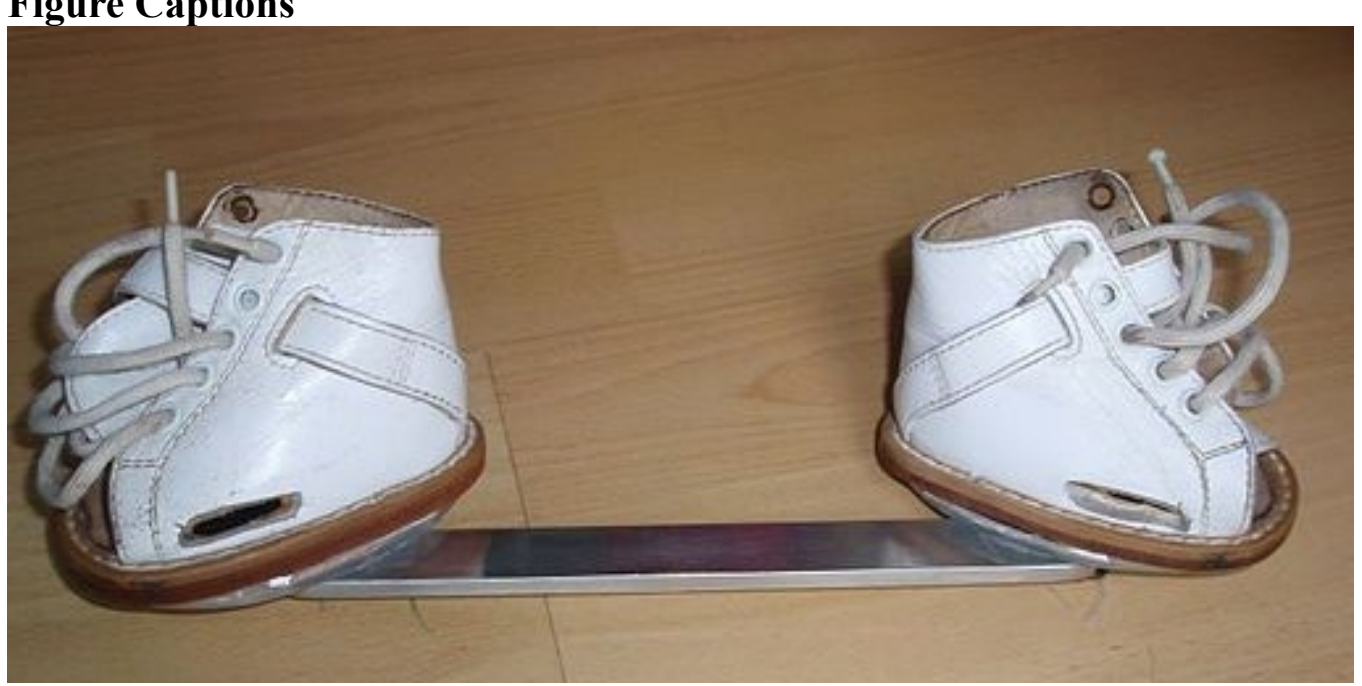

Figure 1 - Simple FAO using the Denis Browne bar (Source:

https://commons.wikimedia.org/wiki/File:Botas.JPG)

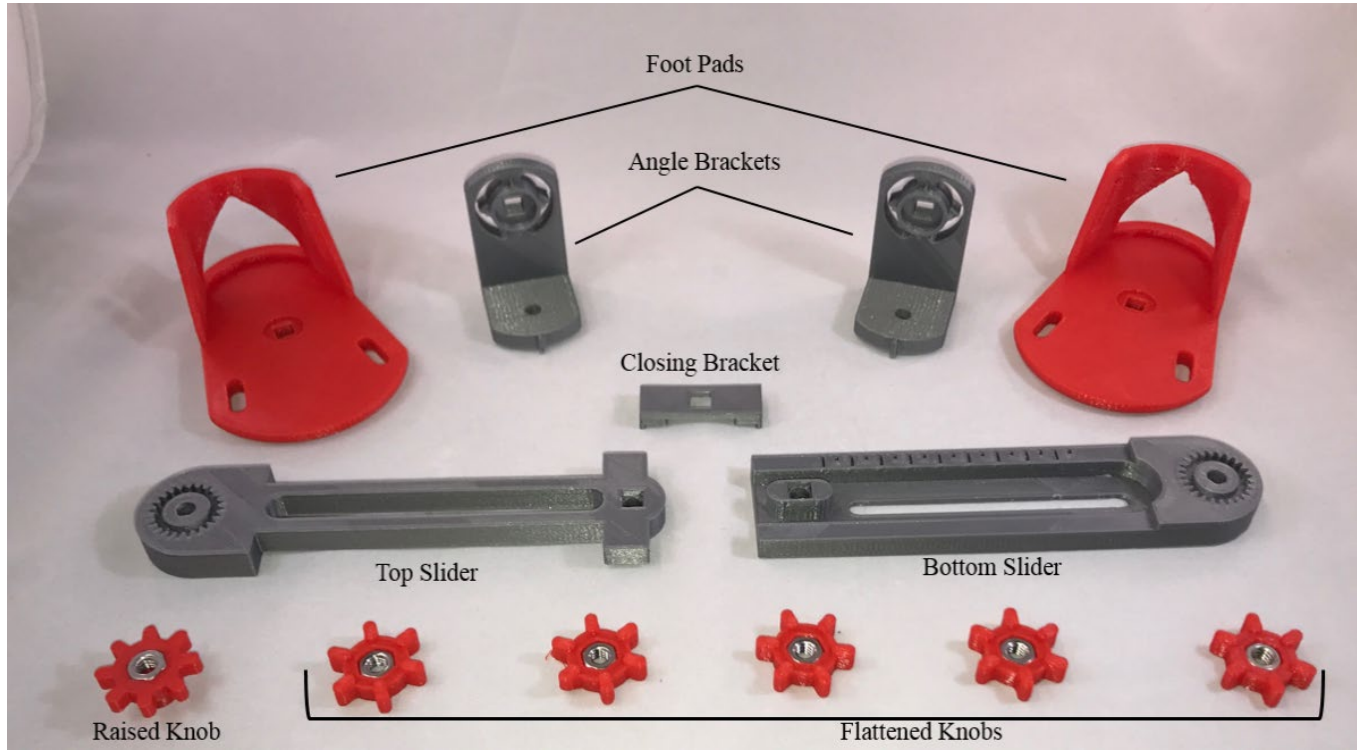

Figure 2 - Bill of Materials all 3-D printed components laid out and labeled. 
Preprint: Savonen, B., Gershenson, J., Bow, J.K.; Pearce, J.M., Open-Source Three-Dimensional Printable Infant Clubfoot Brace, Journal of Prosthetics and Orthotics: 2019. doi: 10.1097/JPO.0000000000000257

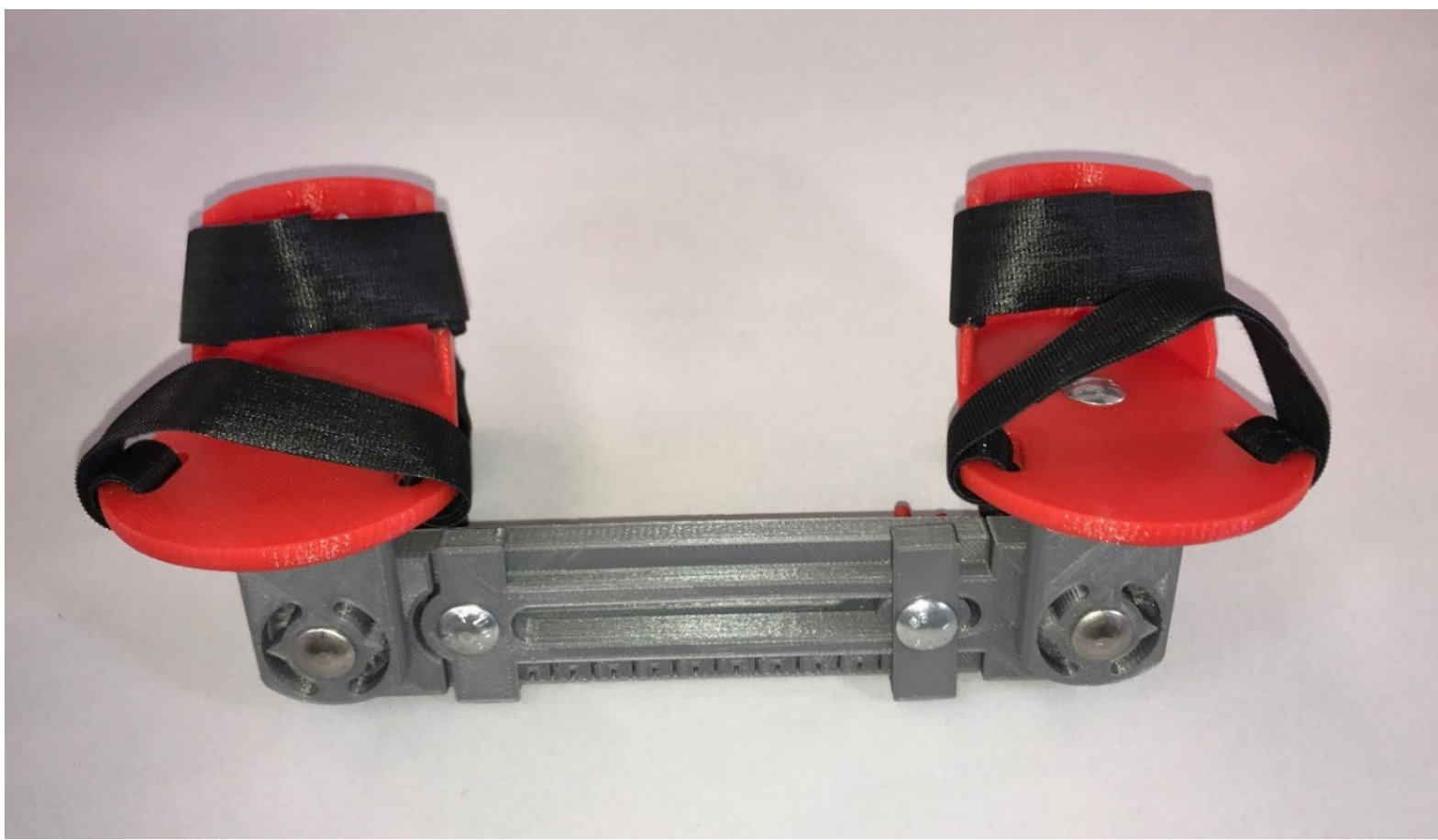

Figure 3 - Angle brackets locked into place.

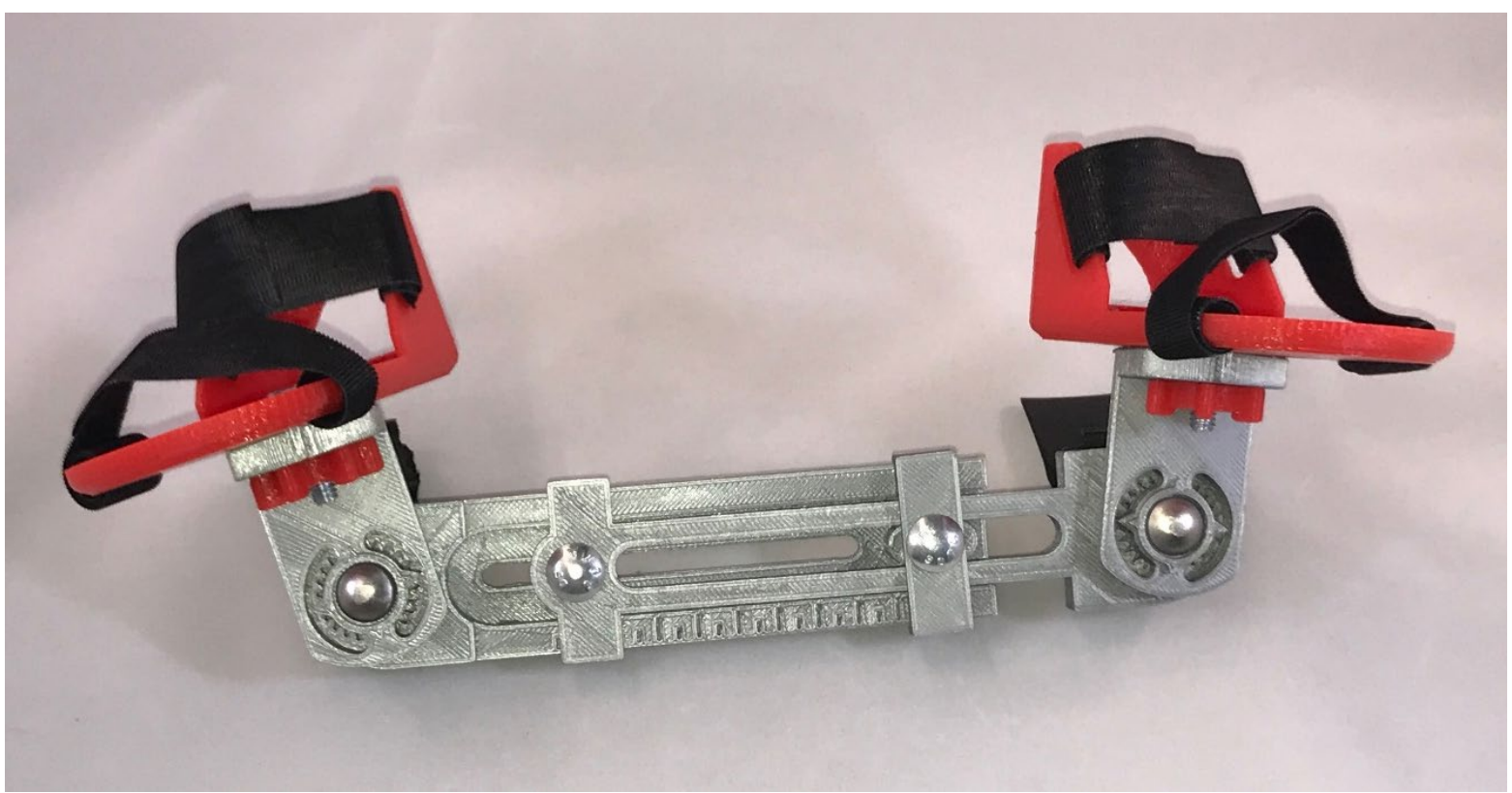

Figure 4 - Angle brackets reversed to allow for increased leg motion. 
Preprint: Savonen, B., Gershenson, J., Bow, J.K.; Pearce, J.M., Open-Source Three-Dimensional Printable Infant Clubfoot Brace, Journal of Prosthetics and Orthotics: 2019. doi: 10.1097/JPO.0000000000000257

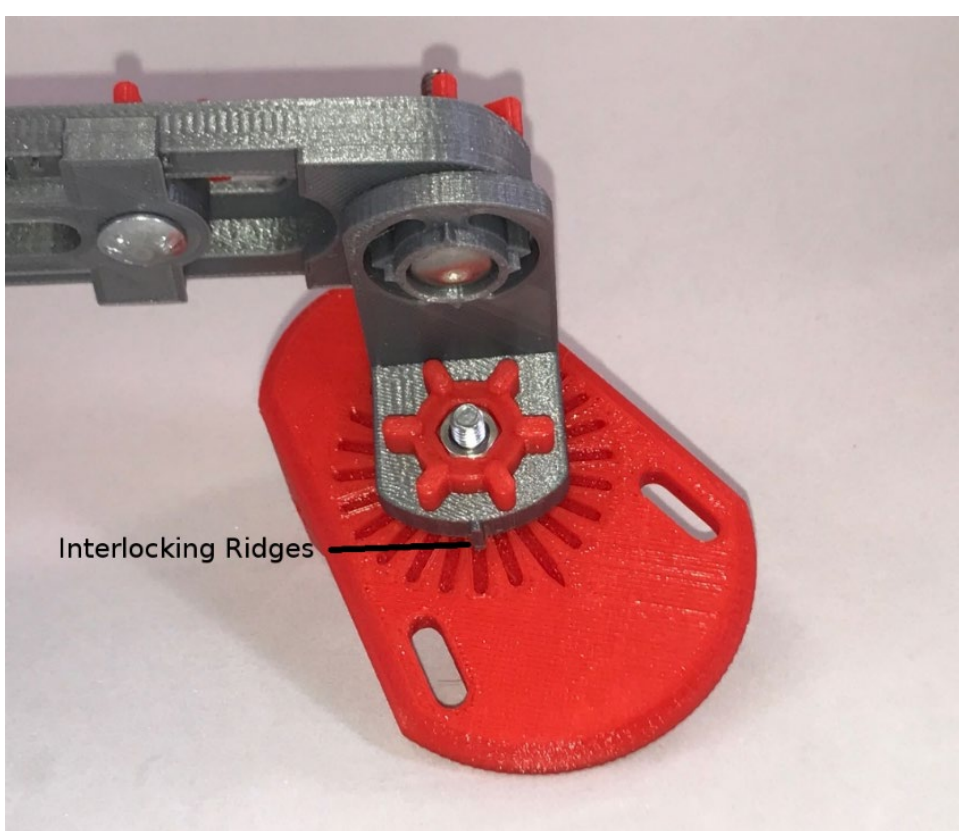

Figure 5 - Attachment of the footpads to the assembly via angle brackets with interlocking ridges to lock footpads into place.

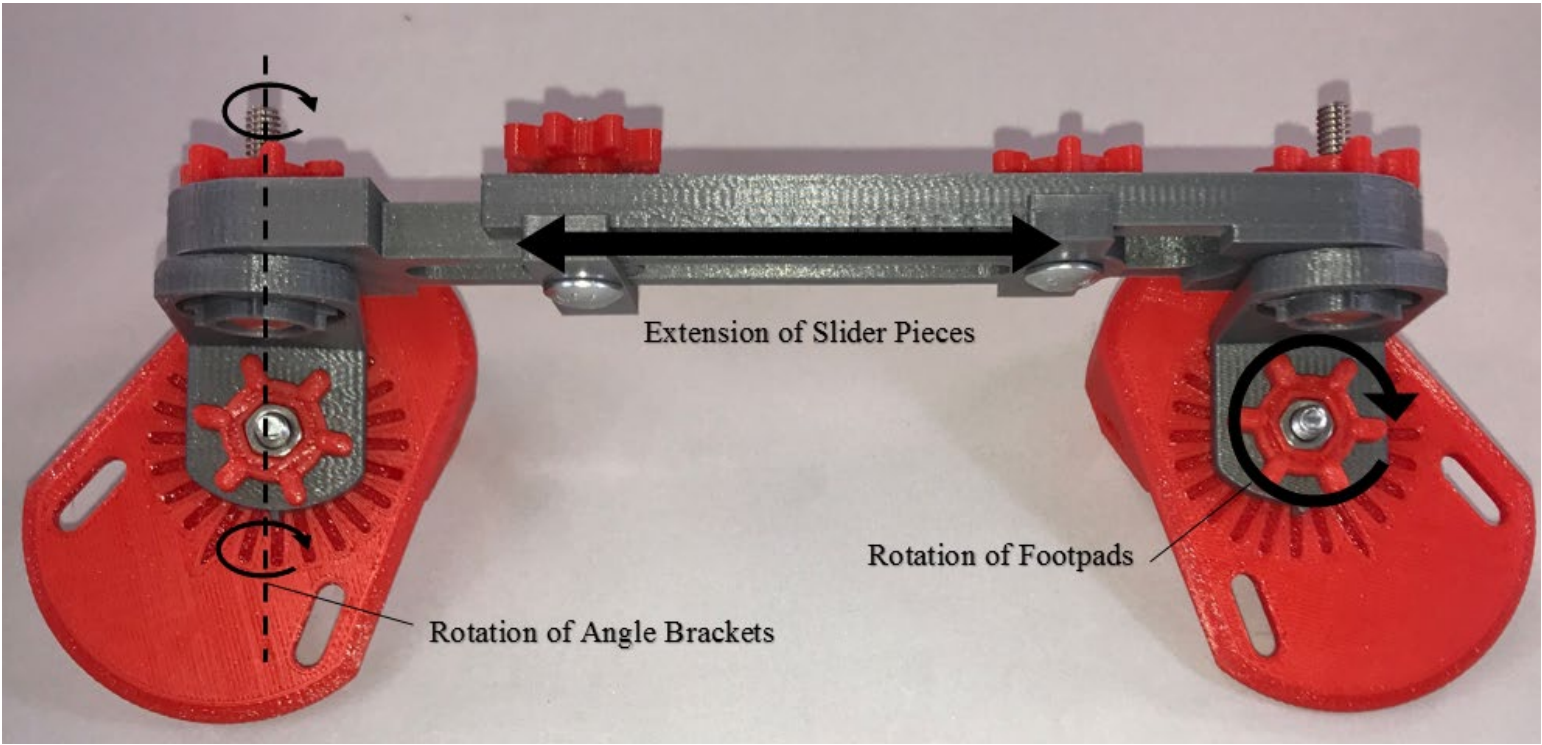

Figure 6 - Fully assembled, showing ranges of motion. 
Preprint: Savonen, B., Gershenson, J., Bow, J.K.; Pearce, J.M., Open-Source Three-Dimensional Printable Infant Clubfoot Brace, Journal of Prosthetics and Orthotics: 2019. doi: 10.1097/JPO.0000000000000257

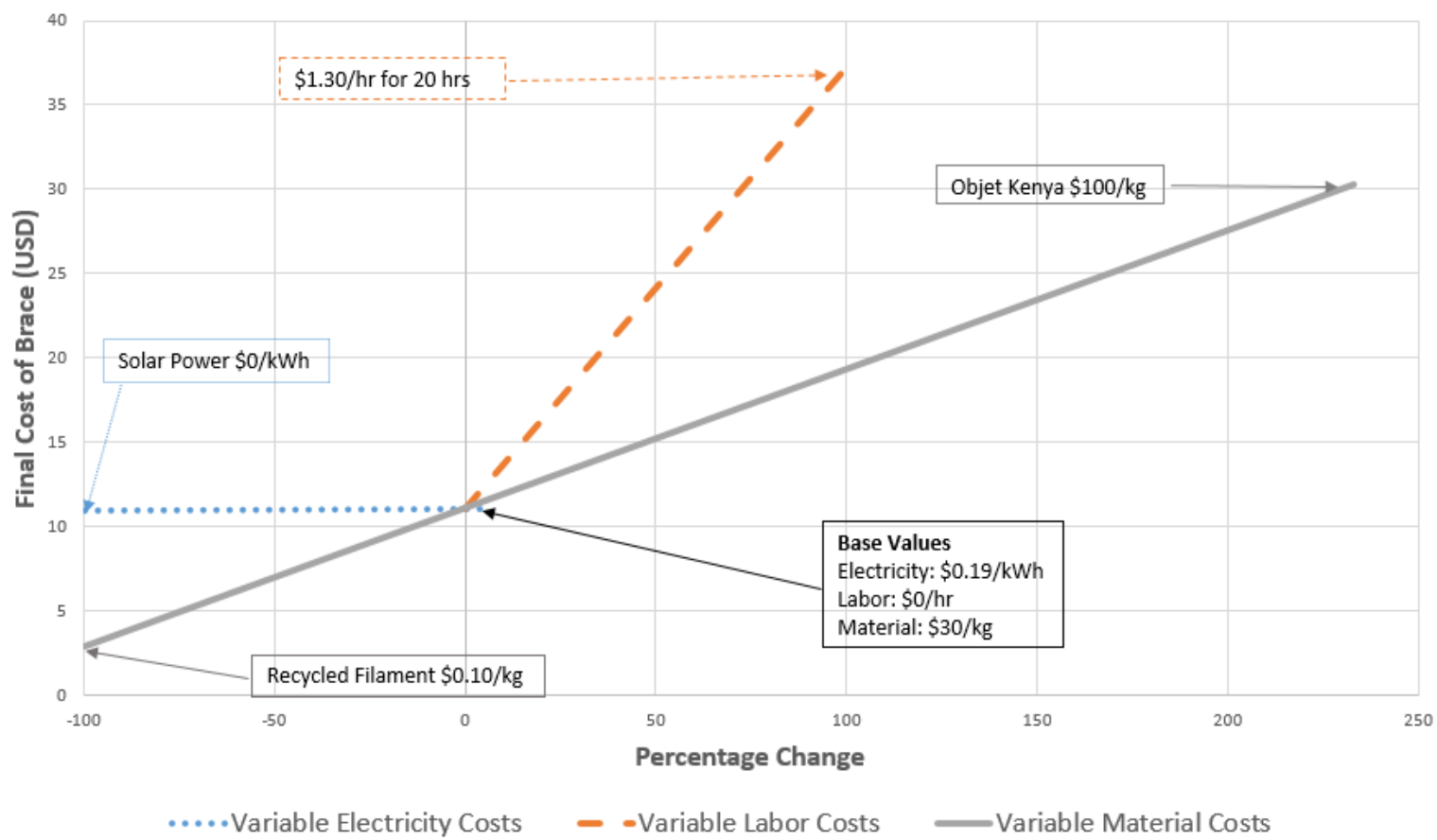

Figure 7. Cost sensitivity analysis: Cost of manufacturing brace vs percentage change in variable costs. 
Preprint: Savonen, B., Gershenson, J., Bow, J.K.; Pearce, J.M., Open-Source Three-Dimensional Printable Infant Clubfoot Brace, Journal of Prosthetics and Orthotics: 2019. doi: 10.1097/JPO.0000000000000257

Table 1. Design criteria for FAOs seen in literature

\begin{tabular}{|l|l|}
\hline Design Criteria & Description \\
\hline $\begin{array}{l}\text { Ability to adjust angle of abduction }{ }^{\mathbf{1 2 , 3 9 -}} \\
\text { Ability to dorsiflex the feet }\end{array}$ & $\begin{array}{l}\text { The f9-41 } \\
\text { of external rotation for affected feet and 20-45 degrees for non- } \\
\text { affected feet. }\end{array}$ \\
\hline Ability to adjust feet width $^{\mathbf{1 2 , 3 9 - 4 1}}$ & $\begin{array}{l}\text { When wearing the brace, the feet should be able to be dorsiflexed to } \\
\text { an angle of 0-20 degrees. }\end{array}$ \\
\hline Allow feet to move independently $\mathbf{4 2}^{\mathbf{2}}$ & $\begin{array}{l}\text { When wearing the brace, the heels of the feet should be adjusted to } \\
\text { be the same distance apart as the width of the infant's shoulders. }\end{array}$ \\
\hline Removable footpads $^{\mathbf{1 2 , 3 9 - 4 1}}$ & $\begin{array}{l}\text { Each foot can move relative to the other foot while maintaining the } \\
\text { necessary outward angle for correction. }\end{array}$ \\
\hline & $\begin{array}{l}\text { Footpads are large enough to accommodate children wearing shoes. } \\
\text { Footpads can be removed for easier application. }\end{array}$ \\
\hline
\end{tabular}

Table 2. Sources of commercial 3-D printer filament (PLA) available in Kenya

\begin{tabular}{|l|l|l|}
\hline Filament Source & $\begin{array}{l}\text { Cost (USD/kg), including } \\
\text { shipping and VAT }\end{array}$ & Source of Data \\
\hline ESun & 30 & Mitchell, B., 2016, personal communication, August 5 \\
\hline AB3D & $\sim 50$ & AB3D-African Born 3D Printing \\
\hline Objet Kenya Limited & 100 & Shah, A., 2016, personal communication, August 12 \\
\hline
\end{tabular}

604

605

Table 3. Bill of Materials 3-D printed components

\begin{tabular}{|l|c|c|r|c|}
\hline Component & Quantity & Print Time (hrs:min) & Mass (gm) & Cost \\
\hline Angle Bracket & 2 & $1: 39$ & 24 & $\$ 0.72$ \\
\hline Bottom Slider & 1 & $3: 36$ & 47 & $\$ 1.41$ \\
\hline Closing Bracket & 1 & $0: 16$ & 4 & $\$ 0.12$ \\
\hline Foot Pad & 2 & $4: 20$ & 39 & $\$ 1.77$ \\
\hline Knob (Flat) & 5 & $0: 14$ & 2 & $\$ 0.09$ \\
\hline Knob (Raised) & 1 & $0: 14$ & 40 & $\$ 0.06$ \\
\hline Top Slider & 1 & $2: 57$ & $\mathbf{2 7 4}$ & $\mathbf{\$ 8 . 2 2}$ \\
\hline Total & $\mathbf{1 3}$ & $\mathbf{2 0 : 1 1}$ & 31.20 \\
\hline
\end{tabular}

607

608

609 
Preprint: Savonen, B., Gershenson, J., Bow, J.K.; Pearce, J.M., Open-Source Three-Dimensional Printable Infant Clubfoot Brace, Journal of Prosthetics and Orthotics: 2019. doi: 10.1097/JPO.0000000000000257

Table 4. Prices of Non-printed hardware $\mathrm{BOM}^{58}$

\begin{tabular}{|l|c|c|}
\hline Component & Quantity & Cost \\
\hline 1/4-20 1" carriage bolt, 18-8 stainless steel & 2 & $\$ 0.20$ \\
\hline 1/4-20 1.25" carriage bolt, 18-8 stainless steel & 1 & $\$ 0.24$ \\
\hline 1/4-20 0.75" carriage bolt, 18-8 stainless steel & 3 & $\$ 0.14$ \\
\hline 1/4-20 hex nut, 18-8 stainless steel & 6 & $\$ 0.04$ \\
\hline Velcro & $1 \mathrm{~m}$ & $\$ 1.40$ \\
\hline Total Cost & & $\$ 2.70$ \\
\hline
\end{tabular}

611

612 
Preprint: Savonen, B., Gershenson, J., Bow, J.K.; Pearce, J.M., Open-Source Three-Dimensional Printable Infant Clubfoot Brace, Journal of Prosthetics and Orthotics: 2019. doi: 10.1097/JPO.0000000000000257

Table 5: Comparison of FAO alternatives

\begin{tabular}{|c|c|c|c|c|c|}
\hline FAO Type & $\begin{array}{ll}\text { 3-D } & \text { Printed } \\
\text { Brace } & \end{array}$ & Ponseti AFO $^{59}$ & Dobbs Bar60 & Steenbeek $^{56}$ & Miraclefeet $^{57}$ \\
\hline Cost & $\begin{array}{l}\$ 11.08 \text { (without } \\
\text { labor commercial } \\
\text { filament) } \\
\sim \$ 37 \text { (with max } \\
\text { labor and } \\
\text { commercial } \\
\text { filament) } \\
<\$ 5 \text { (with } \\
\text { recycled filament } \\
\text { and realistic } \\
\text { labor) }\end{array}$ & $\sim \$ 300$ & $>\$ 300$ & $\$ 10$ & $<\$ 20$ \\
\hline Description & $\begin{array}{l}\text { Low-cost brace } \\
\text { designed for 3-D } \\
\text { printing with } \\
\text { open-source } \\
\text { hardware and } \\
\text { software. }\end{array}$ & $\begin{array}{l}\text { The standard } \\
\text { commercial foot } \\
\text { abduction } \\
\text { orthotic for } \\
\text { children with } \\
\text { clubfoot. } \\
\text { Consists of two } \\
\text { boots connected } \\
\text { by a laterally } \\
\text { adjustable bar. }\end{array}$ & $\begin{array}{l}\text { Modification of } \\
\text { Ponseti AFO that } \\
\text { allows for } \\
\text { increased } \\
\text { mobility through } \\
\text { semi- } \\
\text { independent } \\
\text { motion of the } \\
\text { feet. }\end{array}$ & $\begin{array}{l}\text { Brace specifically } \\
\text { designed for local } \\
\text { manufacture in } \\
\text { Uganda. Uses } \\
\text { local materials } \\
\text { (steel and leather) } \\
\text { and local } \\
\text { craftsmen for } \\
\text { manufacture. }\end{array}$ & $\begin{array}{l}\text { Low-cost, } \\
\text { plastic orthotic } \\
\text { designed by } \\
\text { Standford team } \\
\text { for use in the } \\
\text { developing } \\
\text { world. }\end{array}$ \\
\hline $\begin{array}{l}\text { Locally } \\
\text { manufactured }\end{array}$ & $\begin{array}{l}\text { Yes, with } \\
\text { distributed 3-D } \\
\text { printing }\end{array}$ & No & No & $\begin{array}{l}\text { Yes, with local } \\
\text { materials }\end{array}$ & No \\
\hline $\begin{array}{l}\text { Ability to } \\
\text { adjust angle } \\
\text { of abduction }\end{array}$ & Yes & Yes & Yes & $\begin{array}{l}\text { Yes to a degree as } \\
\text { the angle can be } \\
\text { adjusted by } \\
\text { contouring the bar }\end{array}$ & Yes \\
\hline $\begin{array}{l}\text { Allows for } \\
\text { dorsiflexion } \\
\text { of feet }\end{array}$ & Yes & Yes & Yes & Yes & Yes \\
\hline $\begin{array}{l}\text { Ability to } \\
\text { adjust feet } \\
\text { width }\end{array}$ & Yes & Yes & Yes & No & No \\
\hline $\begin{array}{l}\text { Allows feet to } \\
\text { move } \\
\text { independently }\end{array}$ & Yes & No & Yes & No & No \\
\hline $\begin{array}{l}\text { Removable } \\
\text { footpads }\end{array}$ & Yes & Yes & Yes & No & Yes \\
\hline
\end{tabular}


Preprint: Savonen, B., Gershenson, J., Bow, J.K.; Pearce, J.M., Open-Source Three-Dimensional Printable Infant Clubfoot Brace, Journal of Prosthetics and Orthotics: 2019. doi: 10.1097/JPO.0000000000000257

\section{Table 6. Values used in cost estimation and sensitivity analysis}

\begin{tabular}{|c|c|c|c|c|}
\hline Fixed Inputs & Value & Variable Inputs & Low Value & High Value \\
\hline $\begin{array}{l}\text { Mass of filament used, } m_{p} \text { (from Table } \\
\text { 3) }\end{array}$ & $0.274 \mathrm{~kg}$ & Unit energy costs, $C_{u}$ & $\$ 0 / \mathrm{kWh}$ & $\$ 0.20 / \mathrm{kWh}$ \\
\hline Average power usage during print, $P_{p}$ & $43 \mathrm{~W}$ & Unit cost of filament, $C_{f}$ & $\$ 0.10 / \mathrm{kg}$ & $\$ 100 / \mathrm{kg}$ \\
\hline $\begin{array}{l}\text { Energy consumption for warming the } \\
\text { printer, } E_{w}\end{array}$ & $0.0014 \mathrm{kWh}$ & Hourly wages, w & $\$ 0.00 / \mathrm{hr}$ & $\$ 1.30 / \mathrm{hr}$ \\
\hline Time to print, $t$ & $20.11 \mathrm{hr}$ & & & \\
\hline Cost of additional hardware, $C_{h}$ & $\$ 2.70$ & & & \\
\hline
\end{tabular}

619 